\section{OAK RIDGE Y-12 PLANT}

MARTIN MARUETTA

\section{MICROINDENTATION HARDNESS EVALUATION OF IRIDIUM ALLOY CLAD VENT SET CUPS}

\author{
G. B. Ulrich \\ Materials Engineering Department \\ Development Division \\ L. F. DeRoos \\ Product Evaluation Department \\ Quality Services Division \\ S. E. Stinnette \\ Statistical Applications Department \\ Quality Division
}

Date of Issue: May 15, 1992

Preprint for submission to:

10th Symposium on Space Nuclear Power and Propulsion The University of New Mexico Albuquerque, New Mexico January 10-14, 1993

Prepared by the

Oak Ridge Y-12 Plant

Oak Ridge, Tennessee 37831 managed by MARTIN MARIETTA ENERGY SYSTEMS, INC. for the U.S. DEPARTMENT OF ENERGY under contract DE-AC05-84OR21400

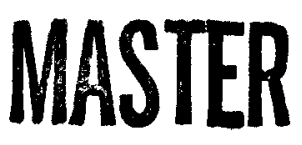

MARTIN MARIETTA ENERGY SYSTEMS, INC. FOR THE UNITED STATES DEPARTMENT OF ENERGY 


\section{DISCLAIMER}

This report was prepared as an account of work sponsored by an agency of the United States Government. Neither the United States Government nor any agency Thereof, nor any of their employees, makes any warranty, express or implied, or assumes any legal liability or responsibility for the accuracy, completeness, or usefulness of any information, apparatus, product, or process disclosed, or represents that its use would not infringe privately owned rights. Reference herein to any specific commercial product, process, or service by trade name, trademark, manufacturer, or otherwise does not necessarily constitute or imply its endorsement, recommendation, or favoring by the United States Government or any agency thereof. The views and opinions of authors expressed herein do not necessarily state or reflect those of the United States Government or any agency thereof. 


\section{DISCLAIMER}

Portions of this document may be illegible in electronic image products. Images are produced from the best available original document. 


\section{DISCLAIMER}

This report was prepared as an account of work sponsored by an agency of the United States Government. Neither the United States Government nor any agency thereof, nor any of their employees, makes any warranty, express or implied, or assumes any legal liability or responsibility for the accuracy, completeness, or usefulness of any information, apparatus, product, or process disclosed, or represents that its use would not infringe privately owned rights. Reference herein to any specific commercial product, process, or service by trade name, trademark, manufacturer, or otherwise, does not necessarily constitute or imply its endorsement, recommendation, or favoring by the United States Government or any agency thereof. The views and opinions of authors expressed herein do not necessarily state or reflect those of the United States Government or any agency thereof.

\section{COPYRIGHT NOTICE}

The submitted manuscript has been authored by a contractor of the U.S. Government under contract DE-AC04-84OR21400. Accordingly, the U.S. Government retains a paid-p, nonexclusive, irrevocable, worldwide license to publish or reproduce the published form of this contribution, prepare derivative works, distribute copies to the public, and perform publicly and display publicly or allow others to do so, for U.S. Government purposes. 


\title{
MICROINDENTATION HARDNESS EVALUATION OF IRIDIUM ALLOY CLAD VENT SET CUPS
}

\author{
George B. Ulrich, Larry F. DeRoos, and Samuel E. Stinnette \\ Oak Ridge Y-12 Plant \\ P. O. Box 2009 \\ Oak Ridge, TN 37831-8096 \\ 615-574-1243
}

$\mathrm{Y} / \mathrm{DV}-1153 / \mathrm{RI}$

DE92 018246

\begin{abstract}
An iridium alloy, DOP-26, is used as cladding for ${ }^{238} \mathrm{PuO}_{2}$ fuel in radioisotope heat sources for space power systems. Presently, DOP-26 iridium alloy clad vent sets (CVS) are being manufactured at the Oak Ridge Y-12 Plant for potential use in the National Aeronautics and Space Administration's Cassini mission to Saturn. Wrought/ground/stress relieved blanks are warm formed into CVS cups. These cups are then annealed to recrystallize the material for subsequent fabrication/assembly operations as well as for final use. One of the cup manufacturing certification requirements is to test for Vickers microindentation hardness. New microindentation hardness specification limits, 210 to $310 \mathrm{HV}$, have been established for a test load of 1000 grams-force (gf). The original specification limits, 250 to $350 \mathrm{HV}$, were for $200 \mathrm{gf}$ testing. The primary reason for switching to a higher test load was to reduce variability in the test data. The DOP-26 alloy exhibits microindentation hardness load dependence, therefore, new limits were needed for 1000 gf testing. The new limits were established by testing material from 15 CVS cups using 200 gf and $1000 \mathrm{gf}$ loads and then statistically analyzing the data. Additional work using a Knoop indenter and a 10 gf load indicated that the DOP-26 alloy grain boundaries have higher hardnesses than the grain interiors.
\end{abstract}

\section{INTRODUCTION}

An iridium alloy is used to encapsulate ${ }^{238} \mathrm{PuO}_{2}$ fuel pellets in the General Purpose Heat Source (GPHS) package used in recent United States radioisotope thermoelectric generators (RTGs). These RTGs are generally used for deep space satellite power systems. The GPHS design operating temperature for the iridium alloy cladding is approximately $1573 \mathrm{~K}$. Iridium is used because of its compatibility with the ${ }^{238} \mathrm{PuO}_{2}$ fuel and the external graphitic components. The high melting point of iridium $(2720 \mathrm{~K})$ as well as its excellent resistance to oxidation and corrosion ${ }^{1}$ are also very desirable properties in this application. The iridium alloy cladding provides maximum containment of the plutonia fuel during all mission phases. ${ }^{2}$

The iridium alloy currently used as the fuel cladding, DOP-26, consists of $0.3 \mathrm{wt} \%$ tungsten, 30 to 90 wt ppm thorium, 20 to $80 \mathrm{wt} \mathrm{ppm}$ aluminum, and the balance iridium. This alloy has been used as the fuel cladding material for the National Aeronautics and Space Administration's (NASA) Galileo (mission to Jupiter) and Ulysses (mission to study Sun's polar regions) space probes. Presently, DOP-26 iridium alloy clad vent sets (CVS) are being manufactured at the Oak Ridge Y-12 Plant for potential use in the NASA Cassini mission to Saturn (see Fig. 1).

One of the CVS cup manufacturing certification requirements is to test for Vickers microindentation hardness. The intent of the microindentation hardness specification requirement is to verify further that

\footnotetext{
Managed by Martin Marietta Energy Systems, Inc., for the U.S. Department of Energy under contract DE-AC05-84OR21400.
} 
the $1648 \mathrm{~K}$ vacuum anneal has achieved essentially full recrystallization (grain size evaluation is primary verification) and to serve as an additional quality indicator that no significant material contamination/ embrittlement has occurred (spark source mass spectroscopic analysis is primary indicator). ${ }^{3}$ Sections from 15 annealed CVS cups were tested for Vickers microindentation hardness using 200 grams-force (gf) and 1000 gf loads. The primary reason for switching from the $200 \mathrm{gf}$ test load to the $1000 \mathrm{gf}$ load was to reduce variability in the test data. The mild reduction in variability that was achieved with a higher test load was accomplished by (1) minimizing the indentation diagonal measuring errors with larger indentations, (2) minimizing the effects of superficial sample preparation artifacts with increased indentation depth, and (3) providing an averaging effect of the typical microstructural features - the matrix, grain boundaries, and precipitates - with the increased indentation depth and area. ${ }^{4}$ Another reason for switching to the 1000 gf test load was to establish testing parameter consistency between the cups and the wrought/ground/stress relieved blankstock which has always been tested using a $1000 \mathrm{gf}$ load. Use of a 1000 gf test load also permits full compliance with the required specification, American Society for Testing and Materials (ASTM) E 92-82 ("Vickers Hardness of Metallic Materials"). ${ }^{5}$

The original microindentation hardness specification limits of 250 to 350 Vickers hardness (HV) were for 200 gf testing. The DOP-26 iridium alloy, like many other materials, exhibits microindentation hardness load dependence ${ }^{4}$; therefore, new limits were needed for $1000 \mathrm{gf}$ testing. Initially, the intent was to establish an upper specification limit only. Further consideration dictated that both lower and upper limits be established for 1000 gf testing, preferably with the same $100 \mathrm{HV}$ range that was used for 200 gf testing. The principal reason for keeping both lower and upper limits as well as the same range was to maintain the same production process quality control check. To establish these new limits testing had to be done at both loads on numerous specimens from different ingots.

Earlier efforts to determine whether the $\mathrm{Ir}_{5}$ Th precipitates present in the DOP-26 alloy are harder or softer than the matrix were inconclusive. Follow-up work for this study addressed grain boundary versus grain interior hardness. This was done using a Knoop indenter and a $10 \mathrm{gf}$ test load.

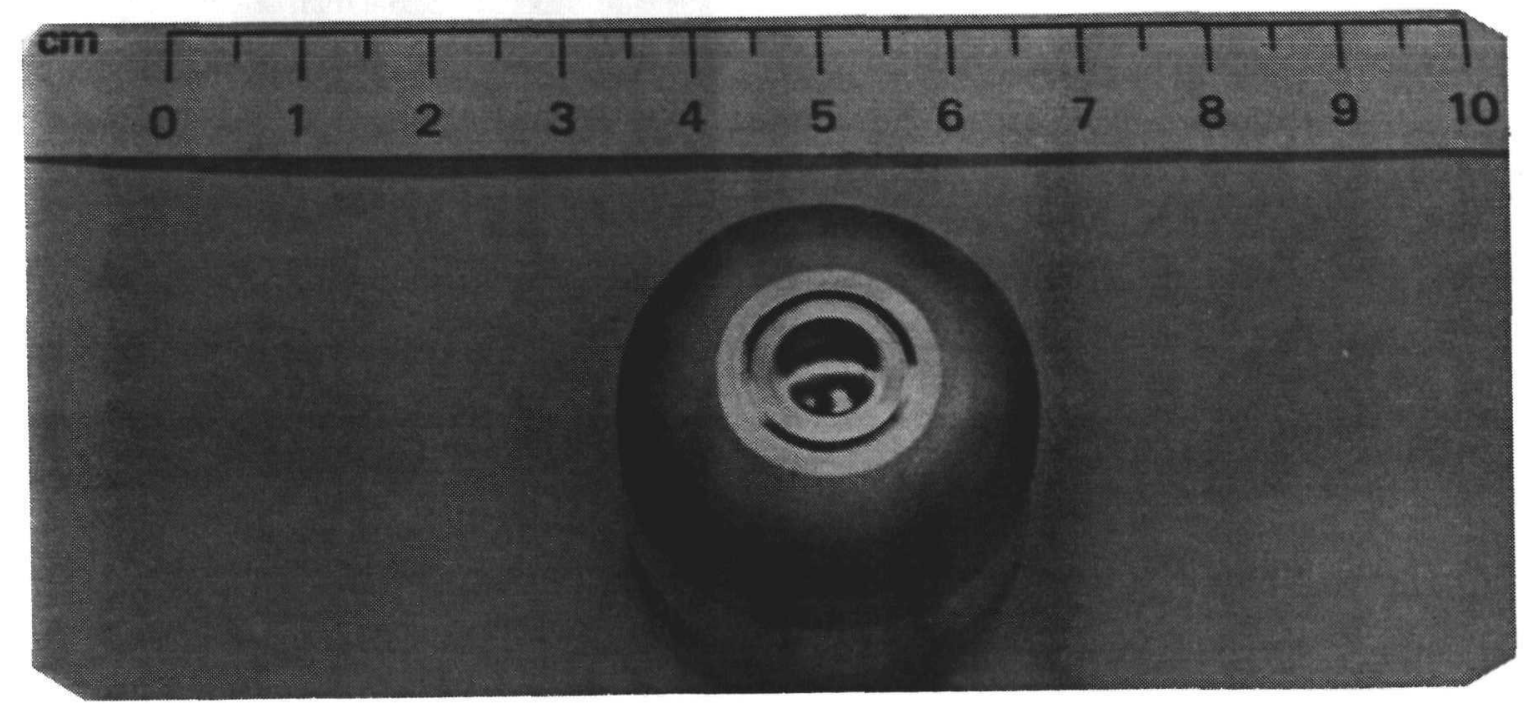

Fig. 1. DOP-26 iridium alloy clad vent set. 


\section{METHODS}

Specification Limit Change Study. The general manufacturing sequences for both the iridium alloy blanks and the clad vent sets have been described previously. ${ }^{4}$ A total of fifteen CVS cups (each from a different heat treat run) were given the standard vacuum $\left(1.3 \times 10^{-2} \mathrm{~Pa}\right)$ anneal at $1648 \mathrm{~K}$ for 1 hour to achieve full recrystallization. These cups represented material from five different $63 \mathrm{~mm}$ diameter ingots. They were then electrical discharge machined (EDM) into sections as shown in Fig. 2. These sections were metallurgically evaluated for grain size, porosity level, and inclusion content to ensure that no anomalous conditions existed before testing for microindentation hardness. The average ASTM grain sizes ranged from 6 to $8(\sim 20$ to $50 \mathrm{rm}$ nominal diameter) while the porosity and inclusion contents were extremely low.

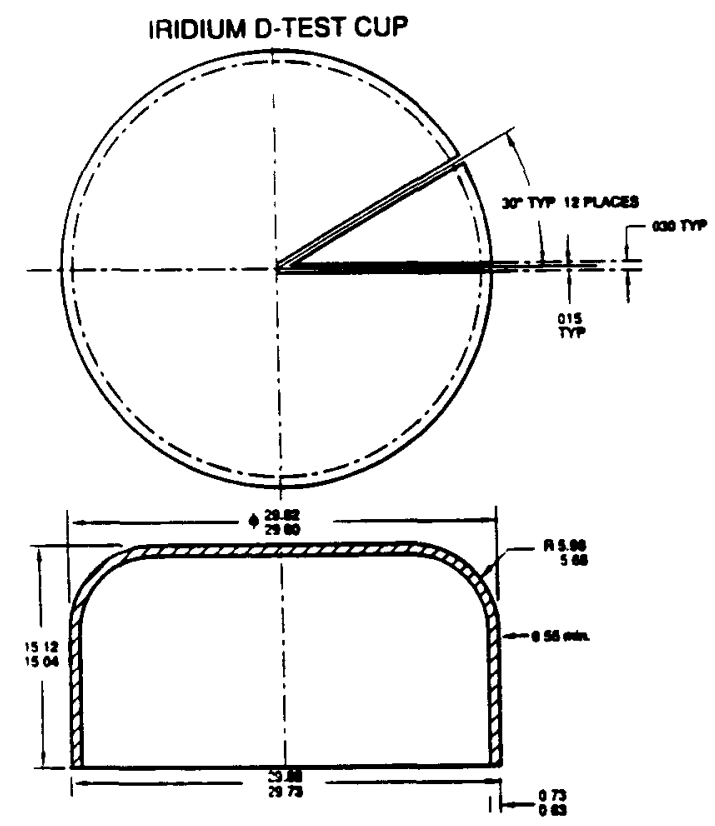

Fig. 2. Clad vent set cup destructive test sections (dimensions in $\mathrm{mm}$ ).

Microindentation hardness testing was performed with a square-based pyramidal diamond indenter using applied loads of $200 \mathrm{gf}$ and $1000 \mathrm{gf}$ according to ASTM E $92-82^{5}$ The testing instrument was a Wilson Tukon Model 200 microindentation hardness tester. A 15 s load duration was used for all tests. The indentation diagonals were measured using a video monitor at approximately $1250 \mathrm{X}$ magnification. The average of three hardness values equivalently normal to the centerline were taken at the pole, radius, and equator of at least four sample sections (early testing was done with six sections) from each cup. The hardness indentations were made after the specimen surfaces were polished, electrolytically etched, and then lightly re-polished with a vibratory polisher.

Grain Boundary Versus Grain Interior Study. Additional work was done to determine whether the grain boundaries are harder or softer than the grain interiors. A cup section (from cup 3625-00-2360/blank E39-4) was tested using the same equipment that was used for the specification limit change study. The testing parameter changes were (1) a Knoop indenter, (2) a test load of $10 \mathrm{gf}$; (3) the indentation diagonals were oriented parallel to the section centerline (followed cup/grain flow contour) in each pole, radius, and equator position; and (4) the sections were given a final light electrolytic etch to reveal the grain boundaries. Ten indentations were made at the grain boundaries (with the short diagonal parallel to 
the boundary thickness or width) and ten within the grain interiors in each pole, radius, and equator position.

\section{RESULTS AND DISCUSSION}

Specification Limit Change Study. The product non-conformance criteria are based on any of the cup section positional averages (hereinafter referred to as "individual values") being outside the specified limits. There were 192 individual values from the 15 cups tested. These individual values for both test loads were statistically analyzed. A summary of the statistical analysis by test load follows.

\section{Statistical Summary of $\mathbf{2 0 0}$ gf Test Load Data - see Fig. 3}

Data passed the test for normality

* Mean - 282.81 HV Standard Deviation - $14.66 \mathrm{HV}$

* Using 3-sigma limits, projected specification limits would be 238.8 to $326.8 \mathrm{HV}$

* Observed minimum and maximum individual values -242.1 and $328.5 \mathrm{HV}$

\section{Statistical Summary of 1000 gf Test Load Data - see Fig. 4}

Data did not pass the test for normality

* Mean - 248.31 HV Standard Deviation - $10.98 \mathrm{HV}$

* Using percentile method $98 \%$ of data found between 229.6 and $287.1 \mathrm{HV}$

* Observed minimum and maximum individual values -228.6 and $288.8 \mathrm{HV}$

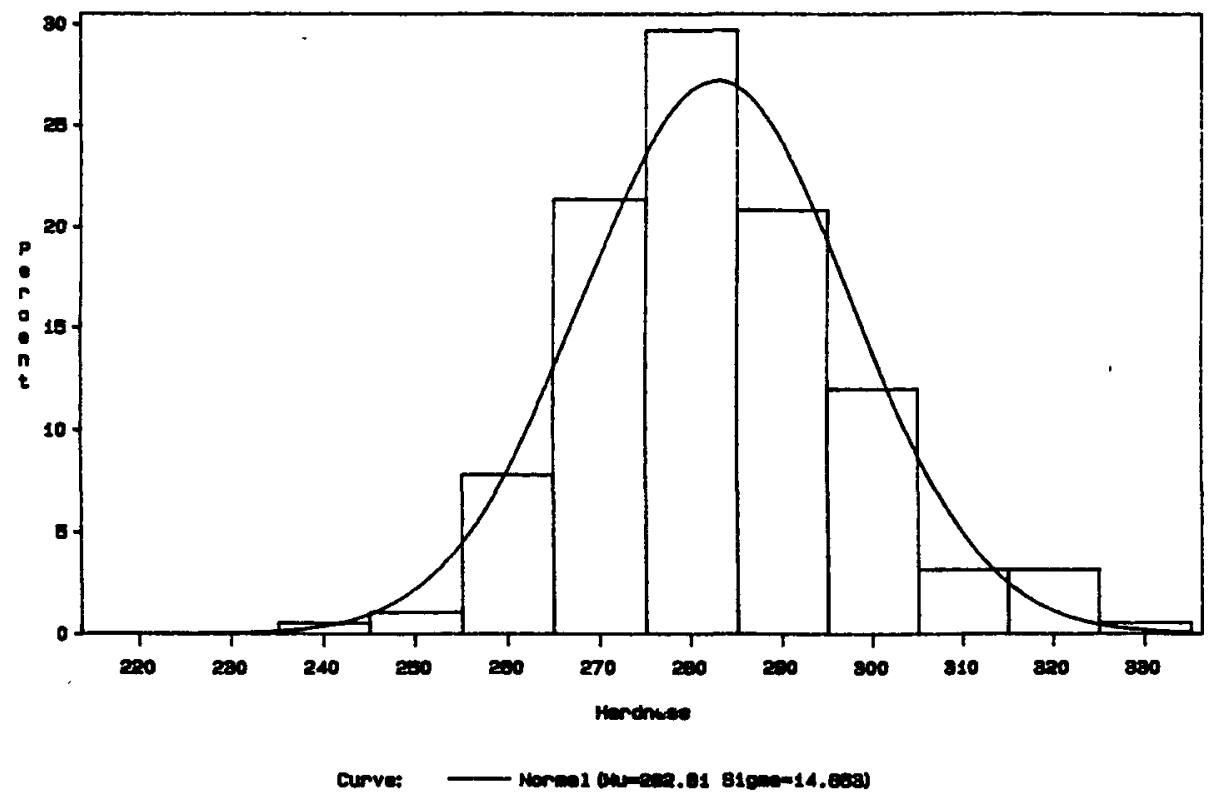

Fig. 3. Distribution of hardness test values for $200 \mathrm{gf}$ test load. 


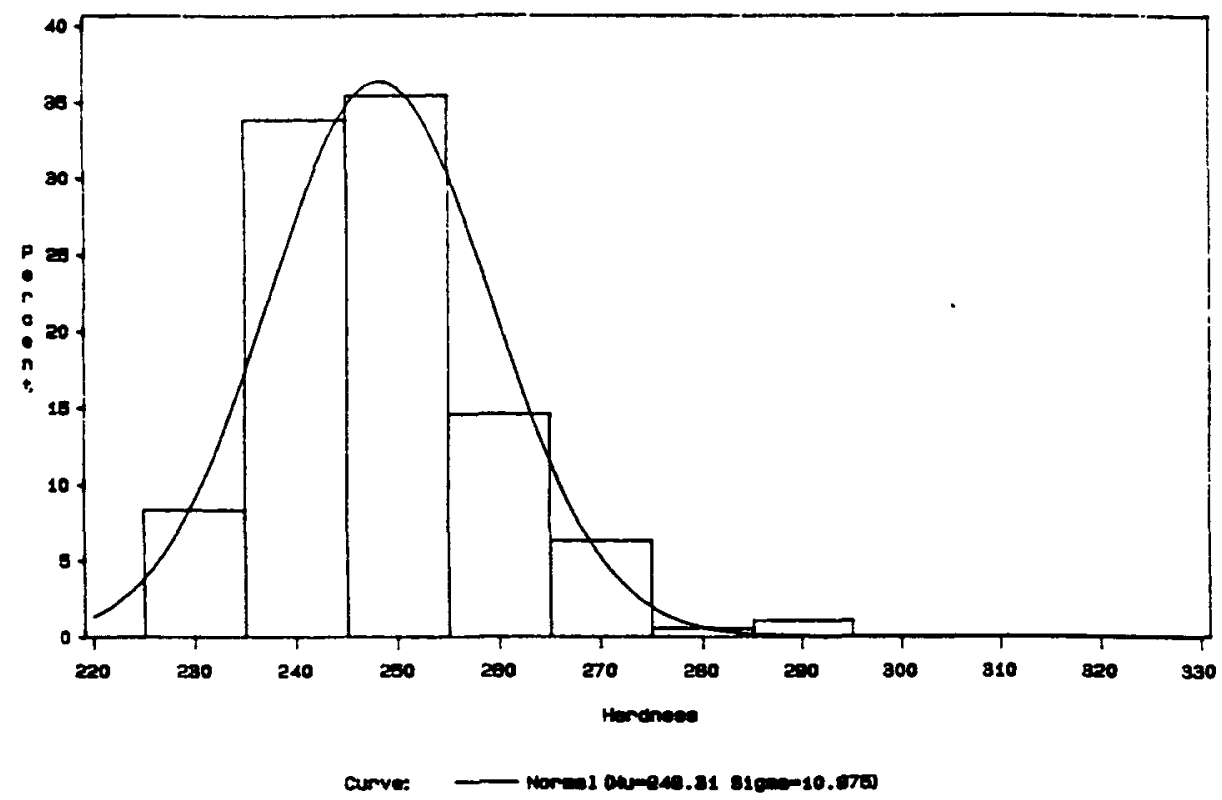

Fig. 4. Distribution of hardness test values for $1000 \mathrm{gf}$ test load.

No statistical differences were found between positions (pole, radius, and equator) at either test load. Also, no consistent relationships were found for parts from the same ingot at either test load. Previous GPHS production data (for Galileo and Ulysses CVS hardware) reported by EG\&G Mound Applied Technologies, Inc. (EG\&G-MAT) had a mean and standard deviation (for 92 cup sections from 46 cups tested using a $200 \mathrm{gf}$ load) of 291.7 and $17.1 \mathrm{HV}$, respectively. The low and high EG\&G-MAT individual values were 257 and $333 \mathrm{HV}$ (after eliminating a low outlier of $242 \mathrm{HV}$ and two high outliers from the same part of 363 and $383 \mathrm{HV}$ ). These data compare favorably with the present 200 gf statistical results. With the present and historical $200 \mathrm{gf}$ results being comparable the present $1000 \mathrm{gf}$ results are expected to be valid for establishing new 1000 gf specification limits.

The upper 3-sigma limit for the Energy Systems 200 gf test load data, $\sim 327 \mathrm{HV}$, indicates that the upper specification limit of $350 \mathrm{HV}$ has a $23 \mathrm{HV}$ "buffer" in it. Applying a buffer of $23 \mathrm{HV}$ to the 99th percentile data generated from $1000 \mathrm{gf}$ testing yields an upper limit of $310 \mathrm{HV}$. The lower 3-sigma limits for both the Energy Systems and EG\&G-MAT 200 gf test load data ( $~ 238$ and $\sim 240$ HV respectively) indicate that occasionally certification values would fall below the apparently arbitrary lower specification limit of $250 \mathrm{HV}$. The 99th percentile lower limit for the Energy Systems 1000 gf test load data of $\sim 229$ $\mathrm{HV}$ indicates that all certification values are expected to be above a $210 \mathrm{HV}$ lower limit. The basis for selecting a rather arbitrary lower limit of $210 \mathrm{HV}$ is to maintain a consistent $100 \mathrm{HV}$ range between the $200 \mathrm{gf}$ and the $1000 \mathrm{gf}$ test load specification limits.

Four iridium alloy samples which were not fully recrystallized after annealing at $1573 \mathrm{~K}$ for $1 \mathrm{~h}$ (instead of the production annealing temperature of $1648 \mathrm{~K}$ ) were tested for microindentation hardness at both $200 \mathrm{gf}$ and $1000 \mathrm{gf}$ loads. This was done to verify that $310 \mathrm{HV}$ is an appropriate upper limit for $1000 \mathrm{gf}$ testing. The samples were from cups formed from blanks C1-8-1 and BR6-8-5. The $200 \mathrm{gf}$ hardness values were consistently above $350 \mathrm{HV}$ when testing in the not-fully-recrystallized areas of each sample, whereas the $1000 \mathrm{gf}$ hardness values were consistently above $310 \mathrm{HV}$. These results verified that both the $200 \mathrm{gf}$ test load upper limit of $350 \mathrm{HV}$ and the new $1000 \mathrm{gf}$ test load upper specification limit of $310 \mathrm{HV}$ will indeed screen out material that is not fully recrystallized. 
Grain Boundary Versus Grain Interior Study. The average and standard deviation Knoop hardness (HK) values for the grain boundaries and grain interiors are shown in Table 2. The data show that the grain boundary averages are 45 to $75 \mathrm{HK}(\sim 10$ to $20 \%)$ higher than those for the grain interiors. These results are not unexpected. ${ }^{6.8}$ Note, however, that for the Ref.8 data the portion of the microindentation hardness difference between the grain boundaries and interiors that can be ascribed to test load ( 5 versus $500 \mathrm{gf}$ ) dependence is not known. The standard deviations (Table 2) for the grain boundaries are also larger than those for the grain interiors. A Knoop indenter was used with the lowest load available, $10 \mathrm{gf}$, to limit the indentation area for the grain boundary testing. Generally, the measured Knoop diagonals were 17 to 20 $\mu \mathrm{m}$ long; therefore, assuming ideal indentations, the short diagonals were 2.4 to $2.8 \mu \mathrm{m}$ long. Other work ${ }^{6-}$ ${ }^{8}$ indicates that the short diagonal should have been small enough to test the "grain boundary hardness." The larger standard deviations for the grain boundary data give an indication of the difficulty in getting the long Knoop indenter diagonal fully aligned on a grain boundary.

Interestingly, a number of similarities exist between the iridium DOP-26 alloy doped with thorium and $\mathrm{Ni}_{3} \mathrm{Al}$ doped with boron, including the following: (1) the reduction of the intrinsic brittleness of the pure materials with their respective dopant additions, (2) dopant segregation to the grain boundaries, ${ }^{9,10}$ and (3) second phase particle formation.,11 Boron, however, is reported to reside interstitially ${ }^{12}$ in solution (up to 0.35 wt $\%$ ) with $\mathrm{Ni}_{3} \mathrm{Al}$, whereas thorium probably resides substitutionally if it has any solubility (<30 $\mathrm{ppm}^{11}$ ) in iridium. Doping $\mathrm{Ir}-0.3 \mathrm{wt} \% \mathrm{~W}$ alloys with thorium tends to increase strength and ductility values slightly when testing at conventional strain rates from room temperature to $1523 \mathrm{~K}$ whereas the effect of boron additions in $\mathrm{Ni}_{3} \mathrm{Al}$ appear to have a more significant effect at conventional strain rates, but the properties of both alloys are temperature and grain size dependent. ${ }^{1314}$ For the DOP-26 alloy both the grain boundary thorium and the $\mathrm{Ir}_{5} \mathrm{Th}$ precipitates are necessary for the desired high temperature impact ductility which is achieved through increased grain boundary cohesive strength and grain size control. ${ }^{10,11}$ Unfortunately, unpublished research by Liu (1981) indicates that there is no correlation between room temperature microindentation hardness ( $200 \mathrm{gf}$ test load) and impact $(61 \mathrm{~m} / \mathrm{s})$ ductility at $1250 \mathrm{~K}$.

Table 2 Grain boundary versus grain interior 10 gf knoop hardness comparison.

\begin{tabular}{|c|c|c|}
\hline POSITION & GRAIN BOUNDARY & GRAIN INTERIOR \\
\hline \hline Equator & $449 \pm 52$ & $404 \pm 29$ \\
\hline Radius & $419 \pm 55$ & $355 \pm 34$ \\
\hline Pole & $425 \pm 59$ & $350 \pm 41$ \\
\hline All Combined & $431 \pm 55$ & $370 \pm 42$ \\
\hline
\end{tabular}

\section{CONCLUSIONS}

Based on this work the following conclusions are made:

1. The previous $200 \mathrm{gf}$ test load specification limits of 250 to $350 \mathrm{HV}$ for the DOP-26 iridium alloy are equivalent to the new 210 to $310 \mathrm{HV}$ limits for $1000 \mathrm{gf}$ testing.

2. The room temperature Knoop microindentation hardnesses (10 gf test load) of the DOP-26 alloy grain boundaries are 10 to $20 \%$ higher than the grain interiors. 


\section{ACKNOWLEDGMENT}

Funding for this work was provided by the U. S. Department of Energy - Office of Special Applications. Special thanks are extended to Dr. W. J. Barnett of the Office of Special Applications for his support of this work.

\section{REFERENCES}

1. Metals Handbook, 10th ed., Vol. 2, Properties and Selection: Nonferrous Alloys and Special-Purpose Materials, pp. 1117-1118, American Society for Metals, Materials Park, Ohio, 1990.

2. G. L. Bennett, J. J. Lombardo, B. J. Rock, "Development and Use of Nuclear Power Sources for Space Applications," The Journal of the Astronautical Sciences, 29, 4, p. 328, Oct.-Dec. 1981.

3. R. W. Zocher, Program Manager Radioisotope Heat Source Fuels and Safety Program, Los Alamos National Laboratory, Los Alamos, NM, personal communication to G. B. Ulrich, GPHS Program Iridium Technical Engineer, Y-12 Plant, Oak Ridge, TN, 1990.

4. G. B. Ulrich, Proceedings of the First International Conference on Heat-Resistant Materials, September 23-26, 1991, Fontana, WI, pp. 187-195, ASM International, Materials Park, Ohio, 1991.

5. ASTM E92-82, "Vickers Hardness of Metallic Materials," Annual Book of ASTM Standards, 3.01, pp. 275-285, ASTM, Philadelphia, 1986.

6. M. Braunovic, C. W. Haworth, and R. T. Weiner, "Grain Boundary Hardening in Iron and Iron Alloys," Metal Science Journal, 2, pp. 67-73, 1968.

7. J. H. Westbrook and H. Conrad, eds., The Science of Hardness Testing and Its Research Applications, pp. 329-376, American Society for Metals, Metals Park, Ohio, 1973.

8. X. R. Qian and Y. T. Chou, "Boron-Induced Softening in Polycrystalline Stoichiometric $\mathrm{Ni}_{3} \mathrm{Al}$ Alloys", Materials Letters, 6, 5,6, pp. 157-160, March 1988.

9. C. T. Liu, C. L. White, and J. A. Horton, "Effect of Boron on Grain-Boundaries in $\mathrm{Ni}_{3} \mathrm{Al}$," $\underline{\text { Acta }}$ Metallurgica, 33, pp. 213-229, 1985.

10. C. L. White, R. E. Clausing, and L. Heatherly, "The Effect of Trace Element Additions on the Grain Boundary Composition of Ir + 0.3 Pct W," Metallurgical Transactions A, 10A, pp. 683-691, June 1979.

11. C. T. Liu, H. Inouye, and A. C. Schaffhauser, "Effect of Thorium Additions on Metallurgical and Mechanical Properties of Ir-0.3 pct W Alloys," Metallurgical Transactions A, 12A, pp. 993-1002, June 1981.

12. S. C. Huang, A. I. Taub, and K. M. Chang, "Boron Extended Solubility and Strengthening Potency in Rapidly Solidified $\mathrm{Ni}_{3} \mathrm{Al}$," Acta Metallurgica, 32, 10, pp. 1703-1707, 1984. 
13. C. T. Liu and $\mathrm{H}$. Inouye, Development and Characterization of an Improved Ir-0.3\% $\mathrm{W}$ Alloy for Space Radioisotope Heat Sources, ORNL-5290, Oak Ridge National Laboratory, Oak Ridge, TN, October 1977.

14. T. P. Weihs, V. Zinoviev, D. V. Viens, and E. M. Schulson, "The Strength, Hardness and Ductility of $\mathrm{Ni}_{3} \mathrm{Al}$ with and without Boron," Acta Metallurgica, 35, 5, pp. 1109-1118, 1987. 